\title{
economics-of-security.eu
}

Athina Economou and Christos Kollias

\section{Terrorism and Political Self-placement in European Union Countries}

June 2012

Economics of Security Working Paper 73

This publication is an output of EUSECON, a research project supported by the European Commission's Seventh Framework Programme.

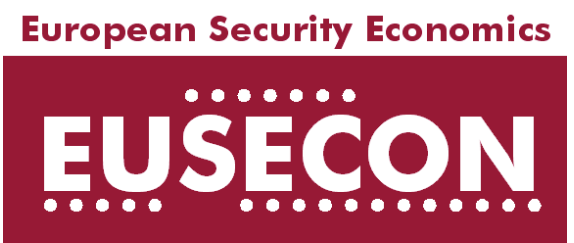

www.economics-of-security.eu

Economics of Security is an initiative managed by DIW Berlin 
Economics of Security Working Paper Series

Correct citation: Economou, A. and Kollias, C. (2012). "Terrorism and Political Selfplacement in European Union Countries". Economics of Security Working Paper 73, Berlin: Economics of Security.

First published in 2012

(c) Athina Economou and Christos Kollias 2012 ISSN: 1868-0488

For further information, please contact:

Economics of Security, c/o Department of Development and Security, DIW Berlin - German Institute for Economic Research, Mohrenstr. 58, 10117 Berlin, Germany.

Tel: $+49(0) 3089789-441$

Email: eusecon@diw.de

Website: www.economics-of-security.eu 


\title{
TERRORISM AND Political SELF-PlacEMENT in
}

\section{EUROPEAN UNION COUNTRIES}

\author{
Athina Economou and Christos Kollias* \\ Department of Economics, University of Thessaly, 43 Korai str., \\ 38221, Volos, Greece
}

\begin{abstract}
Terrorism is widely regarded as a public bad vis-à-vis security - a public good - affecting the subjective well-being of citizens. As studies have shown, citizens' risk-perceptions and risk-assessment are affected by large scale terrorist acts. Reported evidence shows that individuals are often willing to trade-off civil liberties for enhanced security particularly as a post-terrorist attack reaction as well as adopting more conservative views. Within this strand of the literature, this paper examines whether terrorism and in particular mass-casualty terrorist attacks affect citizens' political selfplacement on the left-right scale of the political spectrum. To this effect the Eurobarometer Surveys for twelve European Union countries are utilised and Ordered Probit models are employed for the period 1985-2010 with over 230 thousand observations used in the estimations. On balance, the findings reported herein seem to be pointing to a shift in respondents' self-positioning towards the right of the political spectrum.
\end{abstract}

Acknowledgments: This paper is part of the research project "A New Agenda for European Security Economics", funded by the 7th Framework Program to which financial support is acknowledged.

*Corresponding author: kollias@uth.gr 


\section{Introduction}

Terrorism has been omnipresent throughout history in various forms, shapes and intensity of activity (inter alia: Enders and Sandler, 2012; Shugart, 2006; Kis-Katos et al. 2011; Rathbone and Rowley, 2002). Mega-terrorist attacks such as 9/11 or the 2004 and 2005 Madrid and London attacks and the emergence of transnational terrorism as a major global security threat, has generated a rapidly increasing body of research by scholars from many different fields and disciplines. A plethora of multidimensional issues associated with this phenomenon have been addressed, ranging from its roots, causes and geographical distribution (inter alia: Freytag et al. 2011; Caruso and Schneider, 2011; Krieger and Meierrieks, 2011; Enders and Sandler, 2006; Piazza, 2006, 2008; Li, 2005), to its political and socioeconomic consequences (inter alia: Abadie and Gardeazabal, 2008; Frey et al. 2007, 2009; Turvey et al. 2010; Crain and Crain, 2006; Niskanen, 2006; Brück, 2007; Blomberg et al. 2004), to policies and their effectiveness in thwarting the terrorist threat (inter alia: Enders et al. 1990; Enders and Sandler, 1993, 2000; Bruck, 2005; Brandt and Sandler, 2009; Frey and Luechinger, 2004; Kollias et al. 2009; Drakos and Giannakopoulos, 2009).

A particular strand of this wide ranging and growing literature has focused its attention on how terrorist events affect the political and legislative process and peoples' attitudes, beliefs and electoral behaviour particularly in countries that have fallen victims to terrorism either in the form of systematic terrorist campaigns or from mega-attacks such as the three defining events mentioned above (inter alia: Frey et al. 2009, 2007; Piazza and Walsh, 2009; 
Sharvit et al. 2010; Berrebi and Klor, 2006, 2008; Kurrid-Klitgaard et al. 2006; Rykkia et al. 2011; Dragu, 2011). For instance, Bozzoli and Muller (2011), using the 2005 London attack as a case study, find that peoples' riskperceptions and risk-assessment are affected by such large scale terrorist acts and, as a consequence, individuals are more willing to trade-off civil liberties for enhanced security. Changes towards more conservative attitudes are recorded in a quasi-experimental study by Echebarria-Echabe and FernandezGuede (2006) following the Madrid attacks in 2004. The Mumbai 2008 attacks are used by Finseraas and Listhaug (2011) to asses the impact of terrorism on public opinion. An increase in the fear of terrorism is identifiable in the analysis along with indications that the event in question caused a conservative shift in the left-right division of the political spectrum. Findings reported by studies such as Berrebi and Klor (2006, 2008) and Kibris (2011) indicate that electorate choices are sensitive and seem to respond to terrorist activity, with significant vote shifts in favour of more conservative right-wing parties. Similar influence on the 2004 election outcome in Spain is found by Bali (2007) but in this case causing a shift towards the opposite direction on the political party spectrum in terms of the ballot choices made by the electorate.

In the broader spirit of such studies, this paper addresses a similar question. Using peoples' self-placement on the left-right political scale, it examines whether terrorism affects their political self-positioning just as it apparently does with electoral choices and attitudes towards security enhancing measures and/or terrorist thwarting policies. Essentially, the issue investigated here, is whether terrorist events, and in particular mega-terrorist 
attacks that cause widespread damages and casualties attracting as a consequence intense and widespread media attention worldwide, bring about an identifiable shift in political beliefs and attitudes as these are reflected and captured by the individuals' self-placement on the political spectrum. The question at hand is investigated for twelve European Union countries Belgium, Denmark, France, Germany, Greece, Ireland, Italy, Luxembourg, Netherlands, Portugal, Spain, United Kingdom - over the period 1985-2010 utilizing individuals' responses recorded in the Eurobarometer Surveys.

\section{Background Discussion}

Terrorism is widely regarded as a public bad presenting a major security and political challenge for open societies. Its costs and effects go well beyond the direct damages inflicted by a terrorist attack including the loss of life and injuries (inter alia: Enders and Sandler, 2012; Frey et al. 2007; Niskanen, 2006). Terrorist activity, and in particular the need to defend against it, protect societies from the omnipresent threat and eventually thwart it, often imposes tough choice dilemmas between two public goods: liberties vs security, with the latter potentially involving curtailing civil liberties that epitomize the political achievements and progress of contemporary open societies (inter alia: Piazza and Walsh, 2009; Dragu, 2011; Kurrid-Klitgaard et al. 2006; Niskanen, 2006; Frey and Luechinger, 2004).

As shown by a number of studies, terrorist activity or indeed simply the threat of a terrorist incident often has profound effects on the general public's risk perceptions and attitudes, causing increased insecurity sentiments that 
potentially impact daily social and economic behaviour and generally adversely affecting subjective well-being and life satisfaction (Brück et al. 2011; Frey et al. 2009; Turvey et al. 2010). As already pointed out, it has been shown in a number of studies that terrorist attacks, especially mega-events with significant losses of life and capital that rattle society, bring about a shift towards the support of more conservative policies such as tighter security measures and the concomitant trade-off with civil liberties while voting behaviour is also affected with more conservative parties reaping the electoral benefits in most cases (inter alia: Berrebi and Klor, 2006, 2008; Kibris, 2011; Finseraas and Listhaug, 2011; Echebarria-Echabe and Fernandez-Guede, 2006; Bozzoli and Muller, 2011). This post-terrorist attack conservative shift may not be limited only in the sphere of views, attitudes, preferences and electoral choices. It is possible that terrorist activity (or the threat of it) may also bring about more profound changes in political beliefs and even ideological standing as this is captured by individuals' self-positioning on the left-right continuum of the political spectrum. This hypothesis is put to the test here, utilising the Eurobarometer Surveys where respondents are asked to place themselves on the left-right ideological scale.

The left-right schema is widely accepted as encapsulating and classifying ideologies, political orientation, values, partisan choices and loyalties, political behaviour and policy preferences. Indeed, an individual's positioning on this spectrum is a reflection of his/her social cognition (inter alia: Kroh, 2007; Freire, 2006; Noelle-Neumann, 1998). Clearly, a cohort of factors influence and determine such self-placements by citizens on the leftright dimension. They include ideological leanings and values, political 
preferences and class perceptions, social and demographic characteristics, as well as an individual's current economic circumstances (inter alia: Borooah and van der Ploeg, 1982). Given that terror and in particular mega terrorist events inflict extensive damages and, most important, cause massive fatalities and casualties, it is possible that this could induce more fundamental changes in political perspectives given the recent evidence cited above that points to increased public support for more stringent security measures as well as the willingness to trade civil liberties for security. Hence such shifts in attitudes and preferences may also reflect more profound changes in political beliefs, ideological standing and, consequently, self-placement on the left-right scale. If indeed this is the case, one may intuitively expect a right-wing shift along the political spectrum given that the right is more associated with tighter and stringent security policies and a more stern approach to threats. Nevertheless, one cannot exclude the possibility of a movement towards the opposite end of the spectrum. Clearly, such a shift should not be interpreted as condoning terrorism but rather as indicating a strengthening belief that the only means to uproot terrorism is not through thicker security webs but by addressing its root-causes in a systematic and sustained way that will gradually starve terrorist organisations from their recruiting pools. Hence a leftward shift could be the result of a conviction that one needs to address some of the rootcauses of terrorism such as for instance injustice, oppression, poverty, political repression, ethnic conflict and state failure (Krieger and Meierrieks, 2011; Freytag et al. 2011; Caruso and Schneider, 2011; Bali, 2007).

In the next section we proceed to empirically examine whether or not terrorism causes more profound changes in political beliefs and ideological 
standing in the case of twelve European Union countries. European countries are no strangers to terrorist activity. Europe has been the birth place of some of the best known terrorist groups in the world - such as the Provisional IRA, INLA, ETA, Action Directe, Brigati Rossi, N17, RAF - as well as the venue for attacks of transnational terrorist organisations such as al-Qaida, Black September, Hezbollah and the Abu Nidal Organization. Excluding the damages to capital, property and infrastructures, the operation of both the homegrown as well as the transnational terrorist groups has over the years resulted in tens of thousands of deaths, maiming and injuries for civilians and security personnel alike.

\section{The Methodology}

\section{Dataset \& Variables}

The data used to test the hypothesis are drawn from the Eurobarometer Surveys ${ }^{1}$. They take place more than once each year and they gather information on a representative sample of individuals. The dataset offers a wide range of information concerning individual demographic and socioeconomic characteristics as well as social values self-placements. Unfortunately, not the same individuals are questioned in each wave. Therefore, an independent panel totaling over 230 thousand observations is constructed for the period 1985-2010 for twelve European Union countries Belgium, Denmark, France, Germany², Greece, Ireland, Italy, Luxembourg, Netherlands, Portugal, Spain, United Kingdom - based on the availability of

\footnotetext{
${ }^{1}$ The Eurobarometer surveys were downloaded from http://zacat.gesis.org/.

${ }^{2}$ The data on Germany includes former East Germany from 1990 onwards.
} 
information on the main variable of interest here, namely individual political self-placement. In the surveys, a random sample of individuals in each country is asked to respond to the following question:

- "In political matters people talk of "The Left" and "The Right". How would you place your views on this scale?”.

The respondents' answers are drawn from a ten-response scale with the extreme values being "1: Left" and “10: Right”. Hence, respondents with high rankings on the left-right political scale are considered as more conservative than the rest. In addition, a number of individual demographic and economic characteristics are controlled for, as possible determinants of individual selfplacement on the political scale. Such characteristics are: age, gender, marital status, educational variables and occupational status. Unfortunately, there is no available information for all the years regarding the income of the respondents. Therefore, per capita GDP is also included in the regressions. The data on per capita GDP are drawn from the OECD database3.More details on the variables' descriptions and means are provided in Tables 1 and 2 respectively.

\section{Table 1 around here}

\section{Table 2 around here}

\footnotetext{
${ }^{3}$ Other macroeconomic indicators, such as country unemployment rates and inflation, that could possibly exert an influence upon political self-placement have been also included in the regression models. However, they were either statistically insignificant or highly correlated with GDP, therefore they were excluded from the regressions. Despite the above, the main results of interest remain the same.
} 
In order to examine the central hypothesis of the paper, that is whether terrorist attacks affect individual political self-placement, the main independent variables of interest are mega terrorist events that had a severe impact approximated by the number of casualties they caused. The main criterion for the inclusion of the specific attacks in the study is whether there was a wave available in the Eurobarometer surveys shortly after the attack - up to three months following the event - so that any impact on the selfplacement positioning of respondents would be statistically traceable. The underlying assumption here is that, as time elapses, any potential effect either withers away or that noise from other factors that potentially affect this placement overshadows the effect and hinders traceability. It is hoped that in this manner we will be able to capture any effect terrorist attacks have on political self-placement values. For example, in order to examine the impact of 9/11, information for 2001 was drawn from the survey of the period 17/09/2011-26/10/2011. The only exception to this rule, were the 2004 terrorist attacks in Madrid where there is a gap of approximately seven months between the event and the first survey that followed.

The terrorist incidents that are examined in this study are presented in more detail in Table 3, along with the respective waves that were utilised from the Eurobarometer survey for the years examined. The events are drawn from the Enders and Sandler (2012) mass-casualty terrorist attacks list and, as it can be observed in the relevant table, include 9/11; the 2004 and 2005 bombings in Madrid and London; the 1995 Oklahoma truck bomb; the 1998 al-Qaida attacks against the US embassies in Nairobi, Kenya and Dar es Salaam, Tanzania; the 1993 Bombay bombings by Pakistani agents; the 1985 downing of the Air-India 747 Boeing by Sikh extremists; the 2004 Beslan 
massacre of school children by Chechen rebels and others. For the remaining years, that no major terrorist attacks took place or the attacks coincide with the survey waves, the sample of respondents that participated in the autumn/winter waves is used for each respective country.

\section{Table 3 around here}

\section{Econometric Modelling}

Due to the ordinal nature of the dependent variable, Ordered Probit models are used in the analysis that follows. The latent, not observable, variable of political self-placement $y_{i}^{*}$ depends linearly on the explanatory variables $x_{i}$ :

$$
y_{i}^{*}=\beta^{\prime} \cdot x_{i}+\varepsilon_{i} \quad \varepsilon_{i} \square N(0,1)
$$

Where $y_{i}^{*}$ is the latent, continuous measure of political self placement of individual $i, x_{i}$ is the vector of explanatory variables included in the estimations, $\beta$ is the vector of parameters to be estimated (country and year dummies are also included as controls) and $\varepsilon_{i}$ is the random error term that is assumed to follow the standard normal distribution. With $y_{i}^{*}$ ranging from $-\infty$ to $+\infty$, the dependent variable is expressed as: 


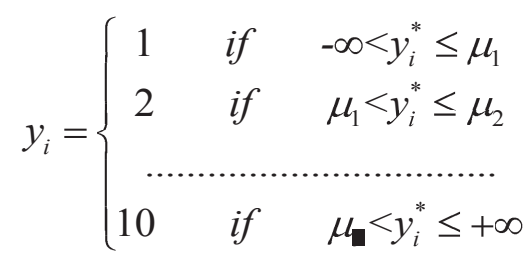

Where the $\mu_{i}$ 's are thresholds to be estimated along with the estimated parameters $\beta$. The method of estimation is Maximum Likelihood4. The effects of terrorism in the Ordered Probit regressions are controlled with dummies taking the value of one if a terrorist event took place shortly before the period of examination and zero otherwise. It was also deemed to be interesting to investigate whether the independent variables exert a differential impact upon individual political self-placement, for each broad category of individuals of "left", "centrist" or "right" political positioning respectively. Based on Eurobarometers' recoding in a three-point scale, individuals are categorised as follows: "1-4: individuals of left political self-placement", "5-6: individuals of center political self-placement", “7-10: individuals of right political selfplacement”. Probit models were also estimated separately for each of the three categories respectively.

Furthermore, Ordered Probit regression models are estimated separately for Spain and the UK since both countries have been the venues of systematic and prolonged terror campaigns from domestic terrorist organisations (mostly by ETA and the Provisional IRA respectively) as well as the targets of transnational terrorist attacks. However, by including in the regression models estimated for these two countries terrorist event dummies

\footnotetext{
${ }^{4}$ In ordered to control for unobserved heterogeneity that might affect the estimated parameters we also estimate heterogeneous choice models (Williams, 2009, 2010). Although there exists unobserved heterogeneity that affects the estimates, the results remain similar.
} 
of the type described above, we in fact treat all events in an equal manner although the impact they might have exerted could be different. Assuming that the impact can be approximated by the number of fatalities of Spanish or British nationals in each incident, an index is constructed using the methodology of Eckstein and Tsiddon (2004) and Kollias et al. (2011). This index is defined as the natural logarithm of fatalities $e+n u m b e r$ of fatalities before each respective period under examination. The data for the fatalities disaggregated by nationality are drawn from internet sources such as Wikipedia, newspapers and websites that provide the full list of victims by nationality for each respective event. Specifically, in the case of Spain, we identified the following fatalities: (i) 2 fatalities of Spanish nationals in the terrorist event of 1985, (ii) 1 fatality in 2001, (iii) 142 fatalities in 20045. In the case of the UK the following information was traced and used: (i) 27 fatalities of British nationality in the 1985 event, (ii) 4 fatalities in 1989, (iii) 67 fatalities in 2001, and (iv) 56 fatalities in $2005^{6}$. In addition, in order to examine whether the terrorist incident had a different effect depending on whether or not it occurred within each of the two countries, we created two separate terrorist indices for domestic and international terrorist events respectively.

Figure 1 around here

\footnotetext{
${ }^{5}$ The terrorist attack of 2004 took place in Madrid. The total number of fatalities was 191 people. An alternative approach would be to model the total number of fatalities since this terrorist attack occurred in Spain and its impact could be independent of the fatalities of Spanish nationals. However, the inclusion of the total number of fatalities in the regressions yielded similar results as the ones presented further down.

${ }^{6}$ The terrorist attack of 2005 took place in London. We could not find a categorization of the victims by nationality so we included the total number of fatalities in the regressions. As in the case of Spain, we believe the results would not be significantly different in either case.
} 
Finally, before proceeding with the estimations and the presentation of the results in the next section, looking at the descriptive statistics of the key variable of interest for our purposes here (Table 2), they reveal that the mean value of individual political self-placement is broadly similar in all the participating countries (Figure 1). The lowest value (indicating more leftist political values) is observed for Spain and Italy while the highest value (indicating more right-conservative political values) is observed for Ireland, followed by Denmark and Greece. Based on the mean values presented in Table 1, the mean age of participants in all countries is at the middle level of the lifecycle, ranging from approximately 44 years in the case of Ireland to 48 years in Germany. Finally, the higher GDP per capita is in Denmark and lowest in Portugal.

\section{The Findings}

Aggregated Sample

The first column of the estimated models in Table 4 presents the results of the pooled dataset regressions. Regarding the main relationship of interest, i.e. that between political self-placement and terrorist events; the findings show that four terrorist attacks are positively and significantly associated with political self-placement. In particular, all the terrorist events that occurred in the years 1985, 1995, 2001, 2002 and 2005 increase the probability of respondents to report higher values in the political self-placement scale (i.e. more conservative values). These incidents are the defining events of the 9/11 attacks and the 2005 London bombings by homegrown terrorists with alQaida ties; the Oklahoma City truck bomb attack in 1995 by Timothy 
McVeigh; the 1985 downing of the Air-India 747 Boeing by Sikh extremists and the barricade hostage seizure of a Moscow Theatre by Chechen terrorists in 2002. The rest of the terrorist events that were used here are found to be insignificant in statistical terms. Namely, the terrorist events that took place in 1989, 1993, 1998 and 2004 are not found to exert any impact on political selfplacement. Perhaps, the most surprising finding is the absence of any effect in the case of the two major terrorist attacks that occurred in 2004. The first one is the Madrid bomb attacks while the second one is the Beslan tragedy in September 2004. The absence of any statistically significant effect in the case of the 2004 Madrid incident may be attributable to the large time window between the occurrence of the event and the time of the survey (approximately seven months). Unfortunately, there was no wave available from the Eurobarometer Surveys shortly after this attack and therefore these findings may not lead to reliable inferences. The same tentative explanation may also be cited for the Beslan incident as well as that it has taken place in a geographically distant area from Europe although it did capture intense worldwide attention given the number of children that died in this attack by the Chechen rebels. Perhaps, also noteworthy is that the August 1998 al-Qaida bomb attacks against the US embassies in Nairobi, Kenya and Dar es Salaam in Tanzania do not seem to exert any effect despite their significance both in terms of victims as well as in terms of the symbolic and political importance of the targets.

Table 4 around here 
The last three columns of Table 4 examine the effect of terrorist attacks upon political values for the aggregate categories of the "leftists", "centrists" and "rightists" respectively. This way we can identify in a more detailed manner the differential effects of the independent variable on these three broad groupings. In broad terms, there seems to be a movement from the "left" scales towards the "center" and in the case of some terrorist events, towards the "right" scales of political positioning. In particular, the terrorist attacks of 1985, 1993, 2001, 2002 and 2005 decrease the probability of the respondents to report "leftist" political values. For the first two incidents of 1985 and 1989, respondents have a lower probability to report "centrist" political values as well (third column of Table 4) but they have a higher probability to report "rightist" political values (fourth column of Table 4). Similarly, there seems to be a movement towards more "centric" political placement when it comes to the attacks of 2001 and 2002. This mainly arises from a movement away from "leftist" political values when we compare the estimated effects for these two terrorist attacks as reported in the second and third columns of Table 4 .

Economic conditions seem to also affect political self-placement. Based on the aggregate estimations presented in the first column of Table 4, an increase in GDP per capita is associated with lower probabilities for respondents to report higher values in the political self-placement scale. To put it differently, during periods of economic expansion, respondents are more likely to report lower political placement values, i.e. more towards the center/left of the scale. On the other hand, during periods of economic downturn and recession, respondents become more conservative since 
apparently they have a higher probability to report higher values in the political self-placement scale.

Several other demographic and social factors, namely age, education, marital status and gender are also found, as one would intuitively expect, to affect political values. Worth pointing out is the effect of the occupational status upon political ideology. The first column of Table 4 indicates that the respondents in all occupational categories controlled in the study have a higher probability to report higher values (i.e. more conservative) in the political self-placement scale vis-à-vis the unemployed. This means that labour market participation greatly affects shelf reported political ideology with the unemployed individuals leaning towards the left scale of the political values scale.

\section{The case of Spain}

Spain is treated separately for two reasons. Firstly, in order to examine in more detail the effect of the 2004 Madrid bomb attacks by al-Qaida that were found to be statistically insignificant in the previous estimations for the aggregated EU sample. Secondly, it was thought that examining whether the impact of terrorist attacks is different for countries that have been the actual scene of such an event vis-à-vis the rest, might provide useful insights. The first column of Table 5 shows the results for the Spanish sample. The statistically insignificant relationship between terrorism and political selfplacement does not change even with the inclusion of the "terrorism index" that allows for the fatalities of Spanish nationals in each incident. However the findings change in the second column of Table 5, where two terrorism indices for domestic hits (i.e. the Madrid terrorist attack) and international hits are 
controlled for. Both domestic and international terrorist attacks increase the probability of reporting higher political values (i.e. more conservative). Nevertheless, the magnitude of the domestic terrorism index is weaker in comparison to the respective effect of the international terrorism index. Perhaps this finding has to do with the fact that we control for only a single terrorist incident and hence its effect is attenuated.

\section{Table 5 around here}

The remaining six columns of Table 5 present the regression findings separately for the disaggregated sample groupings by political categories, i.e. the "leftists", the "centrists" and the "rightists" respectively. The stronger effects are found for the "rightist" group the last two columns of Table 5. It seems that terrorism (either aggregated or disaggregated in domestic and international incidents) increases the probability of the respondents to report "rightist" political values. There does not seem to be an effect for the "centrist" sample but the opposite effect is reported for the "leftist" sample, only in the case of terrorist attacks at the international level. In any case, given the findings reported by Bali (2007) concerning the impact the 2004 terrorist attack had on the voting behaviour of the Spanish electorate, the results reported in Table 5 should be treated with caution and perhaps warrant further investigation. 


\section{The case of the United Kingdom}

The case of the United Kingdom is also examined separately due to the fact that fatalities of British nationals are reported and hence it would be interesting to examine the differential effects upon political self-placement. The results presented in the first two columns of Table 6 for the aggregated British sample are quite stronger compared to those for Spain. Both the aggregated terrorism index and the terrorism indices for domestic and international terrorist attacks exert a significant effect upon political selfplacement. This means that terrorist events are associated with a higher probability of respondents to report higher values in the political scale, i.e. to shift in a more conservative direction on the figurative left-right scale.

\section{Table 6 around here}

However, based on the remaining columns with the regressions for the samples of "leftists", "centrists" and "rightists" respectively, there are notable differences vis-à-vis Spain. In this case, the effects of terrorist events are observable mainly for the "leftists" and the "centrists" groups. The findings seem to indicate that terrorist attacks are associated with lower probabilities of respondents to report "leftists" values but higher probabilities to report “centrist” values. Apparently, terrorist incidents seem to mainly direct "leftists" towards more "centric" ideological positions. In the case of Spain, the respective effects are more pronounced for the "leftist" sample and the "rightist" sample. Nevertheless, it should be stressed here that such country differences can also be attributed to a variety of other factors that also affect 
political ideology which, however, could not be controlled for in this study due to lack of relevant information.

\section{Concluding Remarks}

In light of recent evidence indicating that terrorism affects peoples' attitudes, beliefs and electoral behaviour generally causing a shift towards the right of the political spectrum, this paper, using twelve European Union countries as a case study, set out to examine whether major terrorist attacks affect citizens' political self-placement on the left-right scale. To the best of our knowledge, this issue has not been addressed on this scale before. Using citizens' self-positioning as this is recorded in the Eurobarometer Surveys Ordered Probit models were employed with a total of over 230 thousand observations for all twelve countries of the sample that spans the years 19852010. The choice of mass-casualty terrorist events that were drawn from Enders and Sandler (2012) and used in the empirical investigation here, was very much dictated by compatibility issues with the available survey waves in order to statistically capture the possible effect on self-positioning by the respondents. Furthermore, separate estimations were attempted for the case of Spain and the UK on the grounds that both countries have been for many years the victims of systematic terrorist campaigns from domestic terrorist organisations as well as the venues of major transnational terrorism attacks such as the 2004 and 2005 events respectively.

Broadly speaking, the estimations yielded mixed evidence. Out of nine years (with a total of eleven major terrorist events occurring in them) for which a corresponding survey wave was available soon after the incident had 
occurred, only in five cases a strong statistical association was established between the incidents and respondents' self-placement on the left-right political scale. These included the defining events of the 9/11 attacks and the 2005 London bombings as well as the Oklahoma City attack. A notable exception was the Madrid 2004 event and perhaps the 1998 attacks against the US embassies in Nairobi, Kenya and Dar Es Salaam in Tanzania despite their symbolic and political significance.

If a broad generalisation of the obtained results is attempted, then, on balance, it appears that major terrorist attacks (given the selection constraints mentioned above) seem to induce a rightward shift on the political spectrum as this is recorded in the Eurobarometer Surveys. This finding is broadly in line and compatible with the reported results by other studies that have focused on similar research questions. They report a post- terrorist attack willingness to trade civil liberties for more security, adoption of more conservative views and attitudes as well as a vote shift in favour of more conservative political parties. 


\section{References}

Abadie, A., and J. Gardeazabal (2008) Terrorism and the world economy, European Economic Review 52, 1-27.

Berrebi, C. and Klor, E. (2008) Are voters sensitive to terrorism? Direct evidence from the Israeli electorate, American Political Science Review 102, 279-301

Blomberg, B., Hess, G., and Orphanides, A. (2004) The macroeconomic consequences of terrorism. Journal of Monetary Economics 51, 10071032.

Bozzoli, C. and Muller, C., (2011) Perceptions and attitudes following a terrorist shock: evidence from the UK. European Journal of Political Economy 27, S89-S106

Brandt, P. and Sandler, T. (2009) Hostage taking: understanding terrorist event dynamics. Journal of Policy Modeling 31, 758-778

Brück, T., Llussá, F. and Tavares, J. (2011) Entrepreneurship: the role of extreme events. European Journal of Political Economy 27, S78-S88

Brück, T. [Ed] (2007) The Economic Analysis of Terrorism, Routledge

Brück, T. (2005). An economic analysis of security policies. Defence and Peace Economics 16(1), 375-389

Caruso, R. and Schneider, F. (2011) The socio-economic determinants of terrorism and political violence in Western Europe (1994-2007), European Journal of Political Economy 27, S37-S49

Crain, N. and Crain, W. M. (2006) Terrorised economies. Public Choice 128, 317-349

Dragu, T. (2011) Is there a trade-off between security and liberty? Executive bias, privacy protections and terrorism prevention. American Political Science Review 105, 64-78 
Drakos, K. (2010) Terrorism activity, investor sentiment and stock returns, Review of Financial Economics, 19, 128-135

Drakos, K. and Giannakopoulos, N. (2009) An econometric analysis of counterterrorismeffectiveness: the impact on life and property losses. Public Choice 139, 135-151

Echebarria-Echabe, A. and Fernandez-Guede, E. (2006) Effects of terrorism on attitudes and ideological orientation. European Journal of Social Psychology 36, 259-265

Enders, W., and Sandler, T. (2012). The Political Economy of Terrorism. Cambridge University Press, Cambridge.

Enders, W., Sandler, T. and Gaibulloev, K. (2011). Domestic versus transnational terrorism: data, decomposition and dynamics, Journal of Peace Research 48, 319-337

Enders, W., and Sandler, T. (2006). Distribution of transational terrorism among countries by income class and geography after 9/11. International Studies Quarterly 50, 367-393

Enders, W., and Sandler, T. (2000). Is transnational terrorism becoming more threatening? A time series investigation. Journal of Conflict Resolution, 44(3), 307-332.

Enders, W. and Sandler, T. (1993). The effectiveness of anti-terrorism policies: vector-autoregression intervention analysis. American Political Science Review, 87(4) 829-844

Enders, W., Sandler, T. and Cauley, J. (1990). Assessing the impact of terrorist-thwarting policies: an intervention time series approach. Defence Economics. 2(1) 1-18

Finseraas, H. and Listhaug, O. (2011) It can happen here: the impact of the Mumbai terror attacks on public opinion in Western Europe. Public Choice, DOI 10.1007/s11127-011-9895-7 
Franck, R., Hillman, A. L. and Krausz, M. (2005). Public safety and the moral dilemma in the defense against terror. Defence and Peace Economics, 16(5), 347-364

Freire, A., 2006. Bringing social identities back in: The social anchors of leftright orientation in Western Europe. Intune Project, Working Paper No. MA-07-12.

Freire, A., 2007. Left-right orientations among Europeans: increasingly centrist and/or irrelevant? International Political Science Review 27, 359-378.

Frey, B., Luechinger, S. and Stutzer, A. (2009). The life satisfaction approach to valuing public goods: the case of terrorism. Public Choice, 138, 317345

Frey, B. S. and Luechinger, S. (2004) How to fight terrorism: alternatives to deterrence. Defence and Peace Economics, 14(4), 237-249

Frey, B., Luechinger, S. and Stutzer, A. (2007). Calculating tragedy: assessing the costs of terrorism. Journal of Economic Surveys 21, 1-24

Freytag, A., Kruger, J., Meierriek, D. And Schneider, F. (2011) The origins of terrorism: cross-country estimates of socio-economic determinants of terrorism. European Journal of Political Economy 27, S5-S16

Hodler, R. and Rohner, D. (2012). Electoral terms and terrorism. Public Choice 150, 181-193

Kis-Katos, K., Liebert, H. And Schulze, G. (2011) On the origin of domestic and international terrorism. European Journal of Political Economy 27, S17-S36

Kollias, C., Messis, P., Mylonidis, N. and Paleologou, S. (2009) Terrorism and the effectiveness of security spending in Greece: policy implications of some empirical findings. Journal of Policy Modeling 31, 788-802 
Kurrid-Klitgaard, P., Justesen, M. and Klemmensen, R. (2006) The political economy of freedom, democracy and transnational terrorism. Public Choice 128, 289-315

Kroh, M. (2007). Measuring left-right political orientation: the choice of response format. Public Opinion Quarterly, 71, 204-200.

Krieger, T. and Meierrieks, D. (2011). What causes terrorism? Public Choice, $147,3-27$

Li, Q. (2005). Does democracy promote or reduce transnational terrorist incidents? Journal of Conflict Resolution, 49(2), 278-297.

Mueller, D. (2007) Rights and citizenship in a world of global terrorism, in T. Bruck [Ed]

Niskanen, W. (2006) The several costs of responding to the threat of terrorism. Public Choice 128, 351-356

Noelle-Neumann E., (1998). A shift from the right to the left as an indicator of value change: a battle for the climate of opinion. International Journal of Public Opinion Research 10, 317-334.

Piazza, J. (2006) Rooted in Poverty?: Terrorism, poor economic development, and social cleavages. Terrorism and Political Violence 18(1) 159-177.

Piazza, J. (2008) Incubators of terror: Do failed and failing states promote transnational terrorism. International Studies Quarterly 52 469-488.

Piazza, J. and Walsh, J. (2009) Transnational terror and human rights. International Studies Quarterly 53, 125-148

Rathbone, A. and Rowley, C. (2002) Terrorism, Public Choice 111, 1-10

Rohner, D. and Frey, B. (2007) Blood and ink! The common-interest-game between terrorists and the media. Public Choice, 133, 129-145

Rykkja, L., Laegreid, P. and Fimreite, A. (2011) Attitudes towards anti-terror measures: the role of trust, political orientation and civil liberties support. Critical Studies on Terrorism 4, 219-237

Sharvit, K., Bar-Tal, D., Raviv, Am. Raviv, Al. and Gurevich, R. (2010) Ideological orientation and social context as moderators of the effect of 
terrorism: the case of the Israeli-Jewish public opinion regarding peace. European Journal of Social Psychology 40, 105-121

Shughart, W. F. (2006). An analytical history of terrorism. Public Choice, 128, 7-39

Turvey, C., Onyango, B. Cuite, C. and Hallman, W. (2010), Risk, fear, bird flu and terrorists: a study of risk perceptions and economics. Journal of Socio-Economics 39, 1-10

Williams, R., 2009. Using heterogeneous choice models to compare logit and probit coefficients across groups. Sociological Methods and Research, 37(4): 531-559.

Williams, R., 2010. Fitting heterogeneous choice models with oglm. The Stata Journal, 10(4): 540-567. 


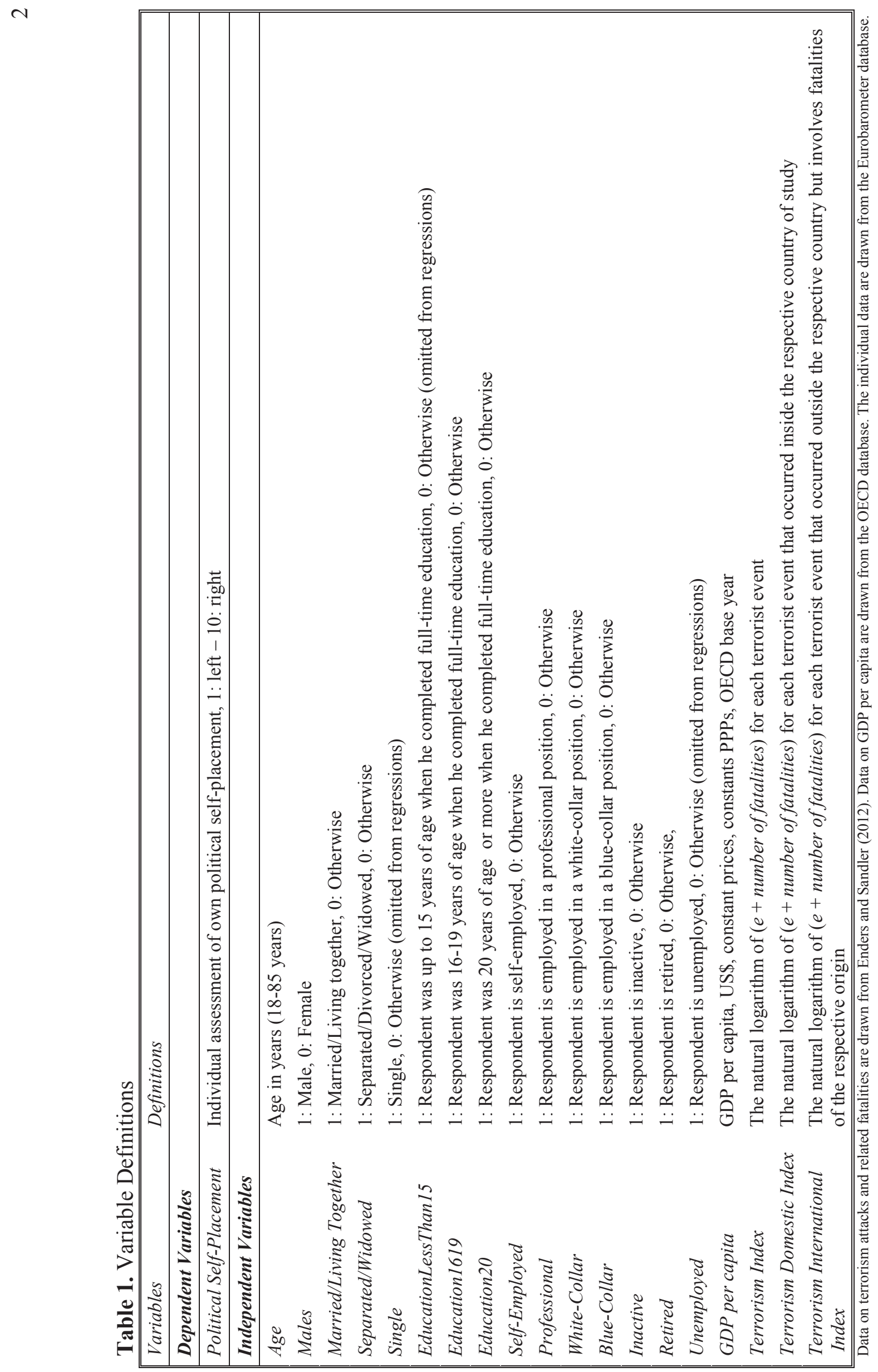




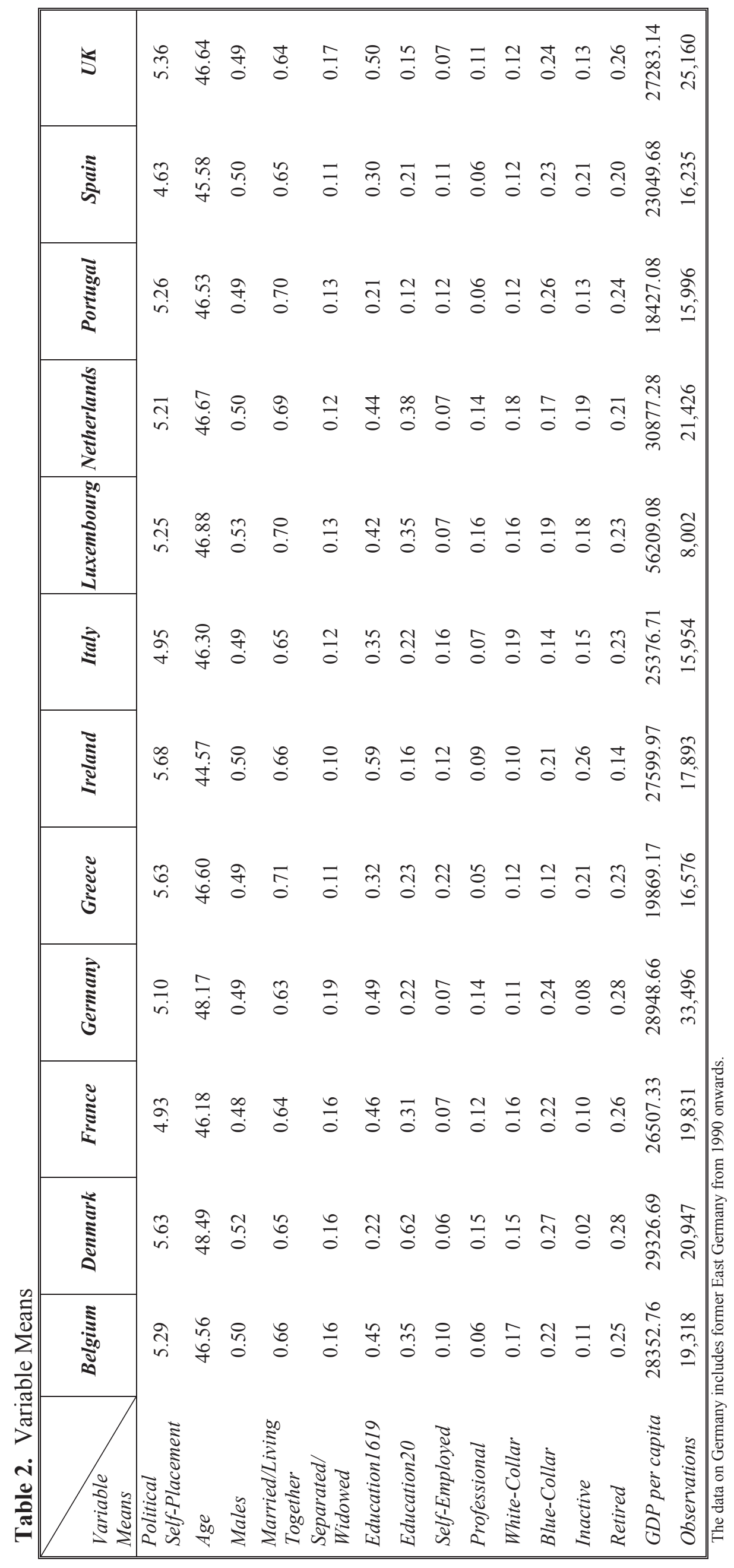




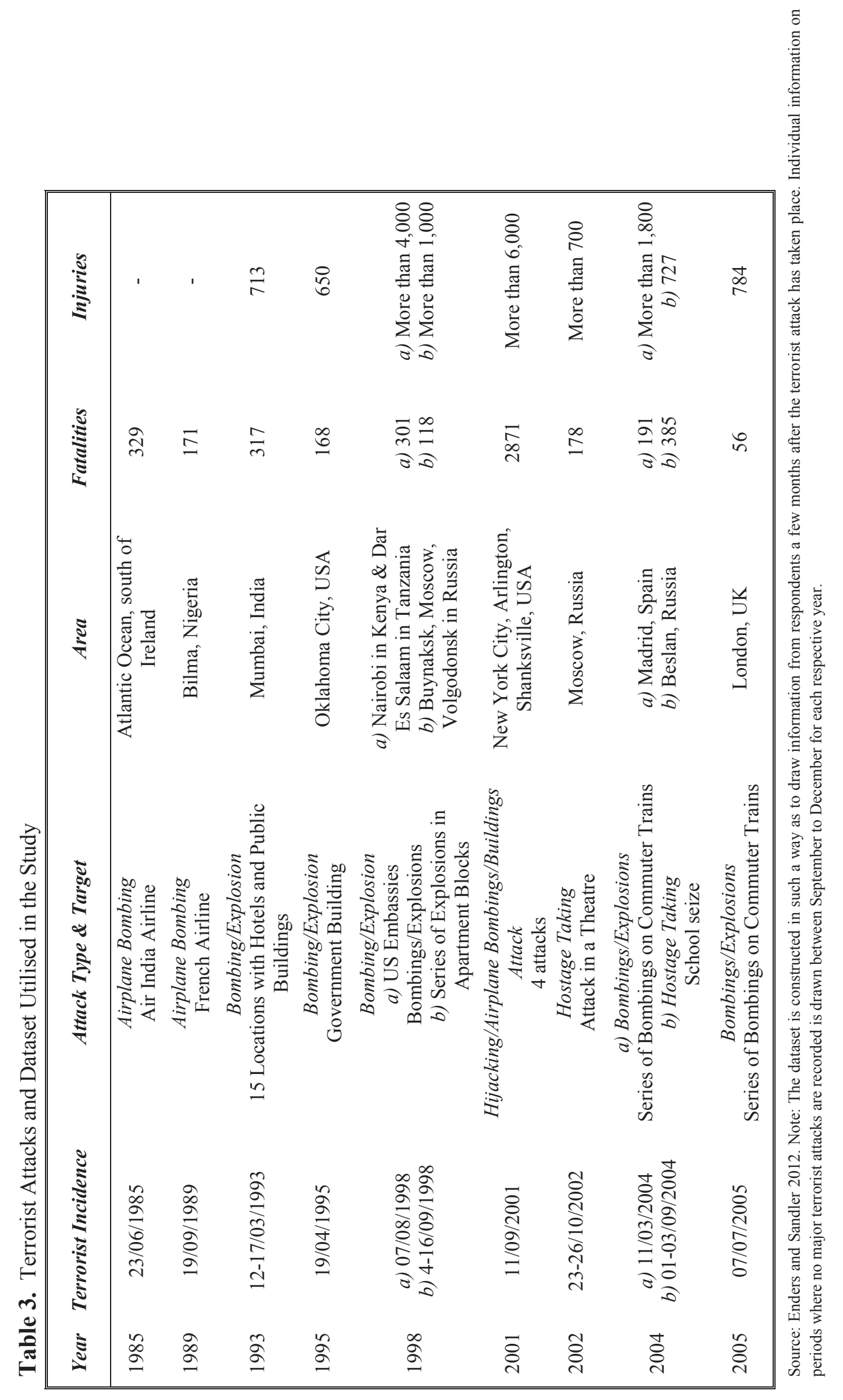


Figure 1. Mean Political Self-Placement Values, 1985-2009

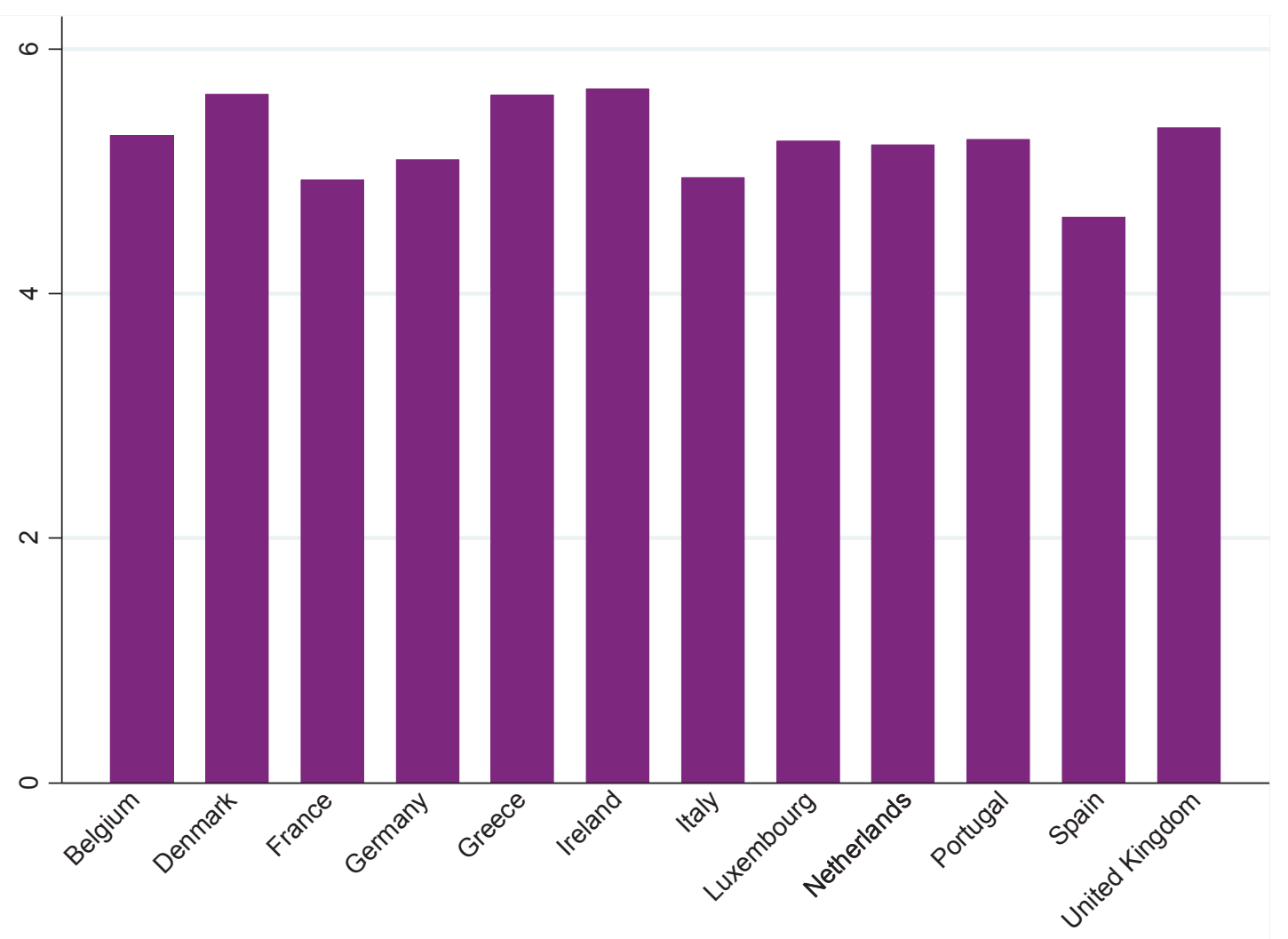

Source: Eurobarometer dataset and own calculations. 
Table 4. The Effect of Terrorist Attacks on Political Self-Placement in the 12 E.U. Countries, 1985-2010

\begin{tabular}{|c|c|c|c|c|}
\hline \multirow[b]{2}{*}{ Indep. Variables } & \multicolumn{4}{|c|}{ Ordered Probit Models } \\
\hline & Total Sample & Left & Center & Right \\
\hline Age & $0.005 * * *$ & $-0.005 * * *$ & $-0.002 * * *$ & $0.007 * * *$ \\
\hline Males & $0.026 * * *$ & $0.036 * * *$ & $-0.116 * * *$ & $0.107 * * *$ \\
\hline Married/Living Together & $0.027 * * *$ & $-0.052 * * *$ & $0.047 * * *$ & $0.027 * * *$ \\
\hline Separated/Widowed & $-0.022 * * *$ & $0.021 * *$ & 0.007 & $-0.022 * * *$ \\
\hline Education1619 & $0.049 * * *$ & $-0.043 * * *$ & $-0.015 * *$ & $0.049 * * *$ \\
\hline Education 20 & $-0.035 * * *$ & $0.117 * * *$ & $-0.139 * * *$ & $-0.035 * * *$ \\
\hline Self-Employed & $0.288 * * *$ & $-0.300 * * *$ & $0.022 * *$ & $0.288 * * *$ \\
\hline Professional & $0.098 * * *$ & $-0.051 * * *$ & $-0.048 * * *$ & $0.098 * * *$ \\
\hline White-Collar & $0.091 * * *$ & $-0.086 * * *$ & 0.017 & $0.091 * * *$ \\
\hline Blue-Collar & $0.047 * * *$ & $-0.072 * * *$ & $0.068 * * *$ & $0.047 * * *$ \\
\hline Inactive & $0.186 * * *$ & $-0.224 * * *$ & $0.062 * * *$ & $0.178 * * *$ \\
\hline Retired & $0.102 * * *$ & $-0.137 * * *$ & $0.057 * * *$ & $0.091 * * *$ \\
\hline Terrorist Attack of 1985 & $0.112 * * *$ & $-0.052 * *$ & $-0.068 * *$ & $0.139 * * *$ \\
\hline Terrorist Attack of 1989 & 0.029 & 0.027 & $-0.102 * * *$ & $0.096 * * *$ \\
\hline Terrorist Attack of 1993 & 0.023 & $-0.039 *$ & 0.034 & 0.002 \\
\hline Terrorist Attack of 1995 & $0.029 *$ & -0.025 & 0.008 & 0.022 \\
\hline Terrorist Attack of 1998 & 0.017 & 0.004 & -0.025 & 0.029 \\
\hline Terrorist Attack of 2001 & $0.028 * *$ & $-0.051 * *$ & $0.043 * *$ & 0.001 \\
\hline Terrorist Attack of 2002 & $0.050 * * *$ & $-0.048 * *$ & $0.034 *$ & 0.012 \\
\hline Terrorist Attack of 2004 & -0.001 & -0.029 & $0.044 * *$ & -0.025 \\
\hline Terrorist Attack of 2005 & $0.061 * * *$ & $-0.035 *$ & -0.027 & $0.073 * * *$ \\
\hline$G D P$ per capita & $-0.00001 * * *$ & $0.00001 * *$ & $0.00001 * * *$ & $-0.00001 * * *$ \\
\hline Country dummies & Yes & Yes & Yes & Yes \\
\hline Year Dummies & Yes & Yes & Yes & Yes \\
\hline $\begin{array}{l}\text { Wald chi2 } \\
(\text { prob }>\text { chi } 2)\end{array}$ & $\begin{array}{c}8541.40 \\
(0.00)\end{array}$ & $\begin{array}{c}7809.90 \\
(0.00)\end{array}$ & $\begin{array}{c}4539.42 \\
(0.00)\end{array}$ & $\begin{array}{c}6001.54 \\
(0.00)\end{array}$ \\
\hline Observations & 230,654 & 230,654 & 230,654 & 230,654 \\
\hline
\end{tabular}

${ }^{a}$ Indicates $* * *$ significance at $1 \%, * *$ significance at $5 \%, *$ significance at $10 \%$.

${ }^{\mathrm{b}}$ All regressions are estimated with heteroskedasticity-robust standard errors. 


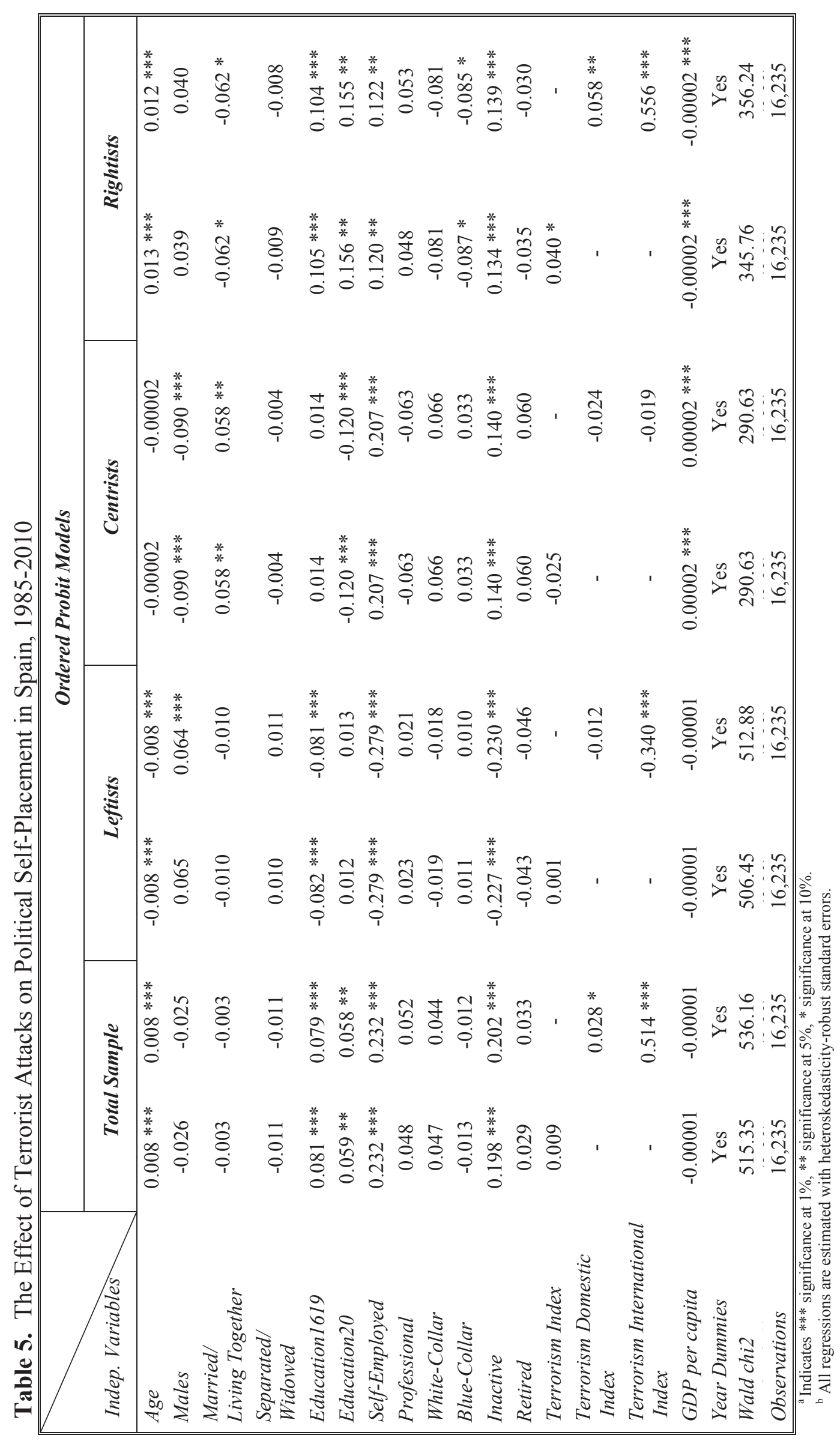




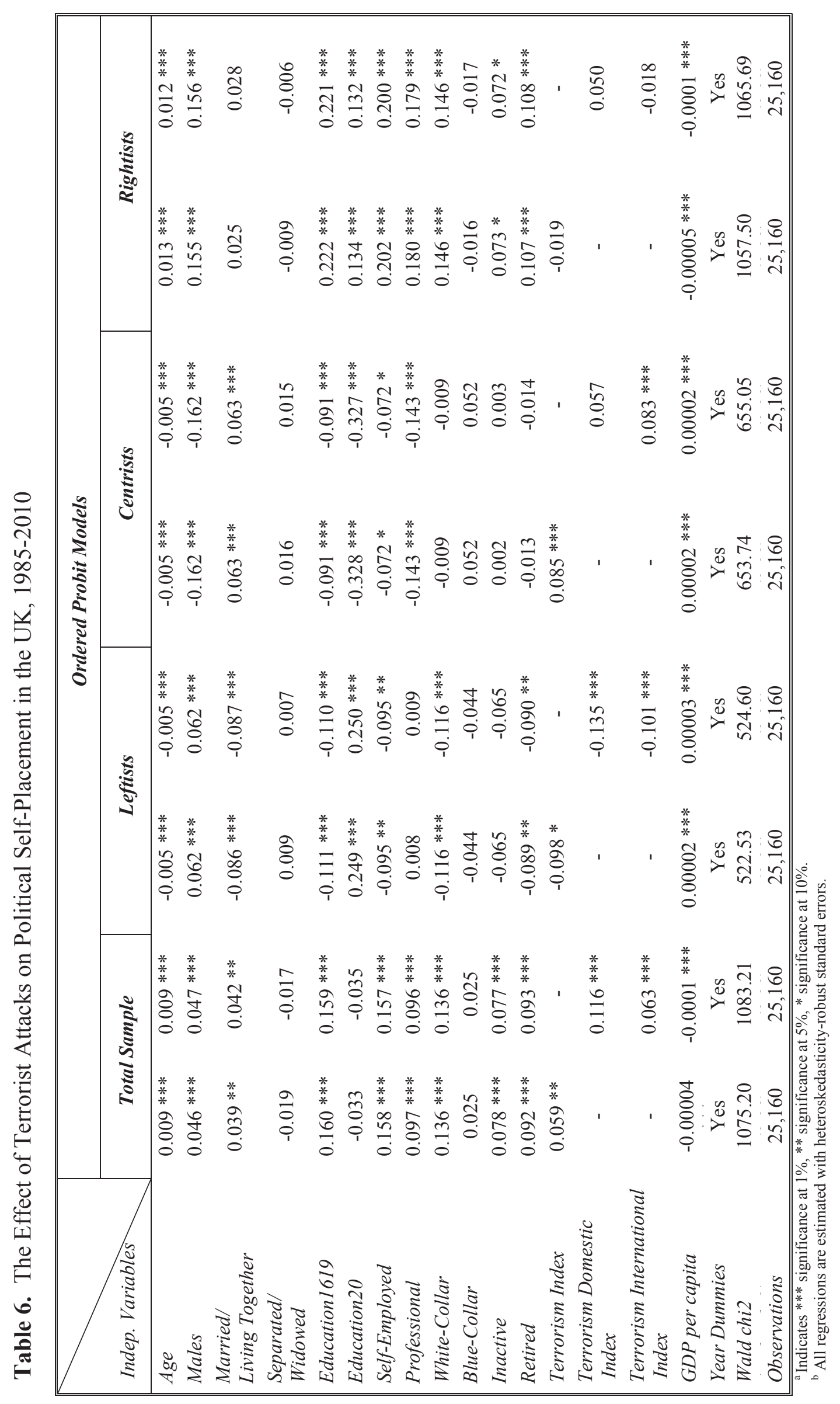

